\title{
Pengembangan Aspek Pemasaran Industri Tahu Sutra Desa Beji Kota Batu
}

\author{
Dicky Wisnu Usdek Riyanto ${ }^{1}$, Novi Puji Lestari ${ }^{*}$ dan Keny Roz ${ }^{1}$ \\ ${ }^{1}$ Universitas Muhammadiyah Malang \\ *Email: novilestari@umm.ac.id
}

\begin{abstract}
Abstrak
Program pengabdian kepada masyarakat yang mengambil obyek di usaha tahu sutra di Desa Beji Kota Batu ini bertujuan untuk mengembangkan beberapa aspek pemasaran. Hasil Identifikasi masalah di lapangan yaitu ditemuakan adalah kurangnya pemahaman tentang konsep pemasaran yang ada di dalam industri ini terkait dengan kemasan di dalam produk juga masih kurang dari kesempurnaan. Kegiatan yang dilakukan oleh tim pengabdian adalah survei lokasi usaha tahu sutra di Desa Beji kemudian tim pengabdian memberikan pengetahuan tentang konsep pemasaran yang jelas dan terkait pentingnya pengemasan suatu produk. Konsep pemasaran yang diberikan antara lain konsep dalam membuat kemasan yang bagus dan tidak mudah diikuti oleh orang lain, penetapan sasaran pasar serta membantu cara pemasaran yang tepat. Dengan program ini diharapkan pengelolaan industri tahu sutra ini dapat berkembang lebih baik dan dapat bersaing dengan produk yang sejenis.
\end{abstract}

Kata kunci: Pemasaran, Industri kecil, Tahu Sutra

\begin{abstract}
The community service program that takes objects in the tofu sutra business in Beji Village, Batu City aims to develop several aspects of marketing. The results of the identification of problems in the field, namely finding out that the lack of understanding of the marketing concepts in this industry related to packaging in the product is still less than perfection. The activity carried out by the service team was a survey of the location of the tofu sutra business in Beji Village and the service team provided clear knowledge of the marketing concept and the importance of packaging a product. The marketing concept provided includes the concept of making good packaging and not being easily followed by others, setting market targets and helping with the right marketing methods. With this program it is expected that the management of the tofu sutra industry can develop better and be able to compete with similar products.
\end{abstract}

Keywords: marketing, small industry,packaging

Format Sitasi: Riyanto D.W, Lestari N.P. \& Rozl K. (2019). Pengembangan Aspek Pemasaran Industri Tahu Sutra Desa Beji Kota Batu. Jurnal Solma, 08(1), 136-141. Doi: http://dx.doi.org/10.29405/solma.v8i1.3071

Diterima: 11 Februari 2019 | Revisi: 16 April 2019 | Dipublikasikan: 30 April 2019.

\section{PENDAHULUAN}

Desa Beji merupakan salah satu bagian desa di wilayah Kecamatan Junrejo yang mempunyai dataran tinggi dan terletak di kiri kanan jalan utama menuju Kota Batu setelah memasuki Desa Mojorejo dan setelah Kelurahan Temas. Desa Beji hanya mempunyai 1 Dusun yaitu Dusun Beji. Masyarakatnya mempunyai mata pencaharian bertani dan sayur 
mayur, ada pula masyarakat beji yang bermata pencaharian sebagai pembuat tempe, oleh karena itu untuk wilayah malang raya khususnya tempe yang dihasilkan Desa Beji ini sangat terkenal.Desa Beji juga terdapat makam bagi pemeluk agama tionghoa atau etnis cina yang luasnya +2 Ha. Nuansa pedesaan di Desa Beji sudah mengarah ke nuansa perkotaan mengingat penduduknya banyak yang berjualan di pusat kota, memang Desa Beji yang aksesnya ke kota memiliki mobilitas sangat tinggi dan juga terdapat perguruan tinggi di Kota Batu yaitu Sekolah Alkitab Batu (SAB). Dalam perjalanan pemerintahan di Desa Beji, guna mempermudah dan memperlancar kegiatan sehari-hari nama jalan protokol yang dulunya Jl. Raya Beji di ganti menjadi Jalan Ir. Soekarno.

Usaha Kecil Menengah (UKM) merupakan salah satu bagian penting dari perekonomian suatu Negara ataupun suatu daerah, tidak terkecuali di Indonesia (Tjiptono, 2005). Usaha kecil dan menengah (UKM) merupakan usaha yang banyak di lakukan banyak orang di indonesia. UKM mulai berkembang dengan pesat setelah terjadinya krisis ekonomi berkepanjangan pada tahun 1997 di Indonesia (Ferrinadewi, 2008). Hal ini berdampak banyaknya terjadi PHK oleh perusahaan-perusahaan besar. Banyaknya karyawan yang di PHK membuat sebagian dari mereka yang mulai mengembangkan berbagai usaha seperti usaha jual beli, bisnis pengolahan dan jasa.Usaha kecil menengah (UKM) di anggap sebagai penyelamat perekonomian Indonesia ketika krisis moneter. UKM di anggap sebagai penyelamat ekonomi karena UKM dapat berperan untuk mengurangi pengangguran dan mampu menyerap banyak tenaga kerja (Muktar, Sukrianti, \& Nurif, 2015). Selain itu Usaha Kecil Menengah juga banyak berkontribusi terhadap pendapatan daerah maupun negara. Adapun ciri-ciri Usaha kecil menengah adalah modal kecil serta resiko tidak terlalu tinggi namun keuntungan yang besar (Philip, 2008).

Usaha Kecil Menengah (UKM) yang terkenal dari desa Beji kota Batu ini adalah penghasil tempe dan tahu, ada berbagai macam tempe dan olahannya yang banyak dimintai oleh masyarakat mulai tempe kedelai, tempe kacang ataupun tempe menjes. Begitu juga dengan olahan tahu namun tahu yang asli dari desa ini masih kalah dengan pabrikan tahu yang juga besar di kawasan kota Batu yaitu tahu Melati dan Nila Sari. Tahu dari Usaha Kecil Menengah Desa Beji ini telah memiliki kualitas yang baik dan berbeda dibanding tahu produksi lainnya namun terkait merek mereka belum mempunyai bidang kesana karena memang minimnya akses dan pemahaman terkait pentingnya merek dalam suatu produk, sehingga produk mereka selama ini sering ditiru oleh pesaing lain. Tim Pengabdian dari Universitas Muhammadiyah Malang ini akan membantu dalam 
pembuatan packing yang bagus dan menarik dan pemberian merek produk serta membantu dalam hal pemasaran.

\section{MASALAH}

Berdasarkan analisis situasi masalah di atas maka identifikasi masalah yang diperoleh oleh tim pengabdian Fakultas Ekonomi dan Bisnis Universitas Muhammadiyah Malang adalah sebagai berikut :

1. Bahwa pada Usaha Kecil Menengah Tahu Sutra ini belum ada standart kemasan yang bagus.

2. Keinginan untuk memiliki rasa bersaing dengan pengusaha sejenis belum ada.

3. Ruang lingkup pemasaran yang masih sempit.

4. Media pemasaran yang masih kurang.

5. Pemahaman akan merek masih tergolong rendah

\section{METODE PELAKSANAAN}

Metode yang kami gunakan adalah menggunakan metode survei, kemudian tim pengabdian akan menganalisis kebutuhan dari sasaran pengabdian ini (Wijayanti, 2012). Setelah itu tim pengabdian akan melakukan pertemuan dengan salah satu pemilik bisnis tahu ini dan kita akan fokus pada perbaikan kemasan dan merk. Permasalahan yang dihadapi mitra adalah banyaknya pesaing yang sudah mulai memproduksi produk yang sama dengan merk yang berbeda sehingga usaha ini kalah dengan yang lainnya. Pemecahan masalah yang disarankan dari tim pengabdian ini adalah memberikan pendampingan terkait kemasan yang menarik dan pemberian merk untuk produksi tahu mereka sehingga tidak mudah pesaing akan menyamai produk mereka. Khalayak sasaran dari kegiatan ini adalah salah satu pemilik usaha tahu sutra yanga da di lingkungan Desa Beji Kota Batu. Produk yang mereka jual kualitasnya sudah bagus namun dari segi kemasan yang masih buruk sehingga mengakibatkan konsumen tidak tertarik membeli produk ini. Metode kegiatan yang dilakukan adalah dengan memberikan materi terkait pentingnya merk dan kemasan yang bagus yang dikemas dalam pertemuan mingguan selama 2 bulan.

\section{PEMBAHASAN}

\section{Gambaran Umum Mitra}

Mitra dari Tim Pengabdian Universitas Muhammadiyah Malang ini adalah salah satu UKM pemroduksi tahu yang ada di Desa Beji Kota Wisata Batu. Usaha tahu dan 
tempe di desa ini sangat maju ,bahkan menjadi langganan baik pasar lokal maupun pasar nasional bagi wisatawan atau pengunjung yang berkunjung ke Kota Batu. Mitra kami terletak di Dusun Sawahan Desa Beji Kota Batu. Kegiatan ini difokuskan pada kegiatan penyuluhan ataupun pendampingan terkait dengan pentingnya sebuah kemasan atau merek bagi sebuah usaha atau bisnis dan pendampingan terkait dengan pentingnya pengepakan yang bagus, serta sistem pemasaran yang cocok untuk industri tahu sutra ini.

\section{Pemecahan Masalah}

Beberapa kegiatan pendampingan dilakukan dalam waktu 3 bulan dan dilakukan setiap hari sabtu, mulai dari persetujuan mitra, pemahaman mereka terkait dengan merek dan kemasan serta tim membantu dalam hal pemasaran. Namun dalam kegiatan ini kami tidak diperbolehkan banyak mengambil gambar dikarenakan sangat rahasia dan kami sdh sepakat untuk tidak mengambil foto kegiatan terlalu banyak. Pemecahan masalah yang kita lakukan pertama adalah sosialisasi terhadap mitra dilanjutkan dengan kegiatan yang sudah kita agendakan. Pemecahan permasalahan yang kedua adalah memberikan edukasi terkait pentingnya pengemasan dan pemberian label atau identitas produk yang telah dihasilkan. Hal ini sangat diperlukan dalam kegiatan bisnis karena bertujuan untuk sebagai identitas produk serta menjadi pembeda dengan produk sejenis. Selanjutnya tim pengabdian Universitas Muhammadiyah Malang membantu dalam proses promosi dan memperluas pangsa pasar. Hasil dari pendampingan ini adalah sebagai berikut :

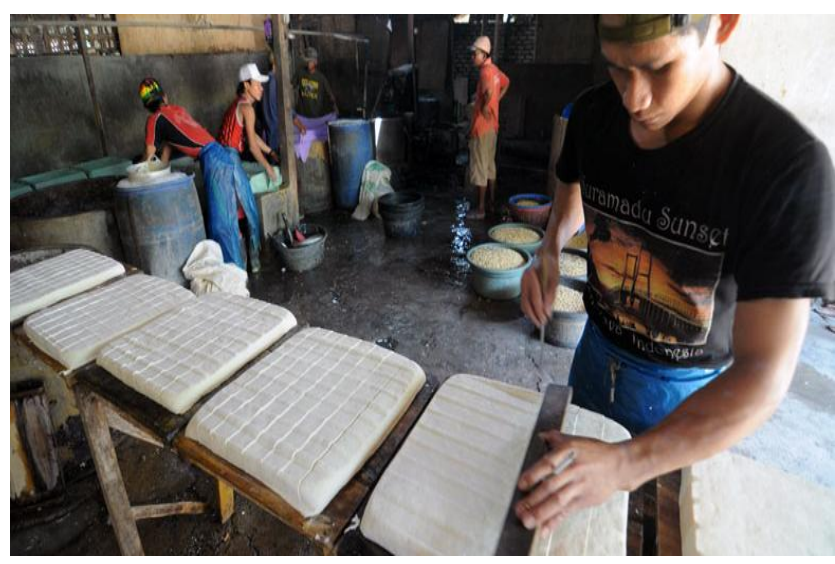

Gambar 1. Proses Pembuatan Tahu Sutra 


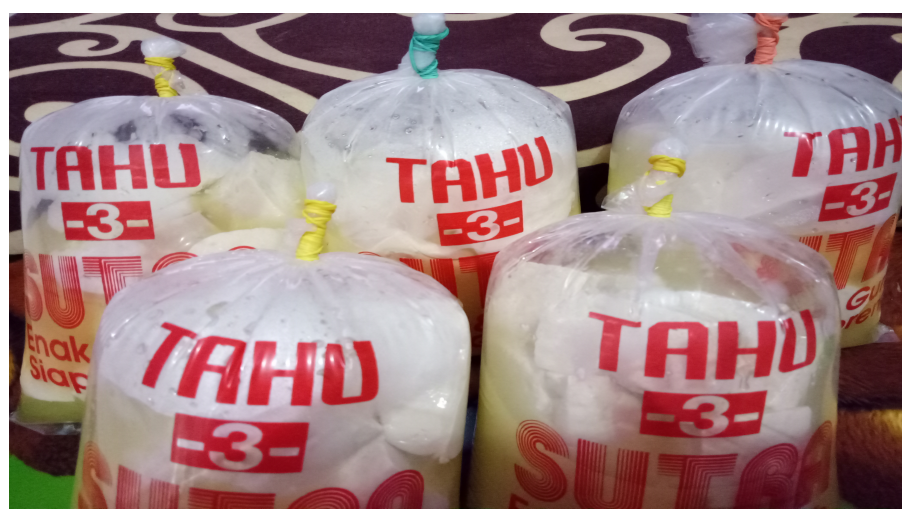

Gambar 2. Hasil dari pengemasan setelah diadakan pendampingan

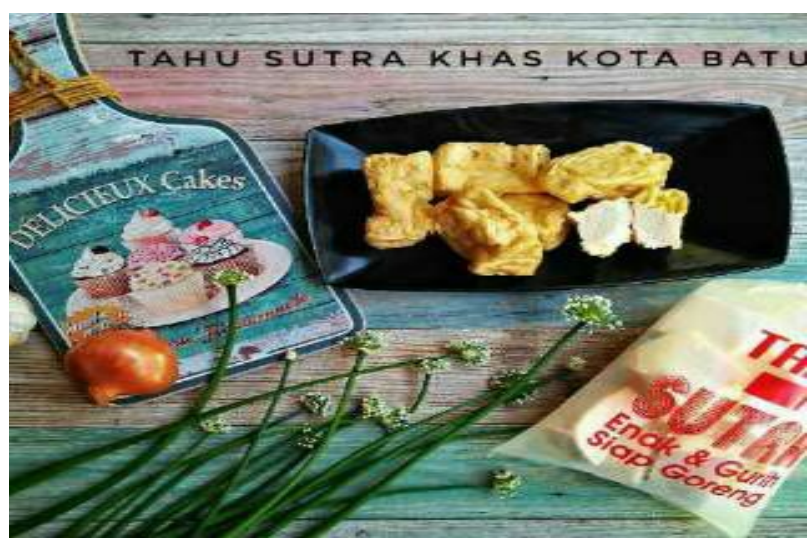

Gambar 3. Metode pemasaran yang digunakan melalui media sosial dan metode word of mouth

\section{KESIMPULAN}

Berdasar kegiatan dalam pengembangan aspek pemasaran tahu sutra di Dusun Sawahan Desa Beji Kota Wisata Batu telah berjalan dengan lancar dan memberikan kontribusi yang lebih kepada mitra. Dengan adanya program pengabdian ini mitra dapat merasakan perbedaan sebelum dan setelah dilakukanya pendampingan yang dilakukan oleh tim pengabdian. Karena setelah kegiatan ini berlangsung banyak permintaan dapat dilayani oleh pengusaha tahu sutra yang menjadi mitra kami, baik permintaan dari masyarakat lokal maupun permintaan dari luar daerah yang akan menjadikan tahu sutra sebagai buah tangan dari Kota Batu. Dengan adanya pendampingan selama dilakukanya pengabdian mitra merasa lebih percaya diri untuk bersaing dengan UKM sejenis karena telah memiliki identitas produk yang berbeda dengan kompetitor serupa lainya. Selama periode kegiatan, terjadi kendala yang dialami oleh tim pengabdian yaitu waktu yang tidak sesuai antara pemilik usaha dengan tim pengabdian karena mereka setiap pagi dan sore selalu melakukan produksi sehingga waktu kita juga tidak dapat maksimal. Kemudian kendala 
yang kedua sifat mitra yang masih tertutup juga menghambat kita untuk pengambilan gambar kegiatan dan sebagianya.

\section{UCAPAN TERIMA KASIH}

Dengan terselesainya kegiatan pengabdian ini, maka kami sampaikan terimakasih yang sebesar-besarnya kepada Rektor Universitas Muhammadiyah Malang, Dekan Fakultas Ekonomi \& Bisnis, beserta jajarannya yang telah memberikan dana kegiatan ini sehingga dapat selesai dengan lancar dan tak kurang satu apapun. Terimakasih juga kami sampaikan kepada pihak mitra yang telah memberi kesempatan dan mau bekerjsama dengan tim untuk melakukan pengabdian masyarakat ini. Semoga apa yang telah tim pengabdian Univeristas Muhammadiyah berikan memberikan efek yang positif bagi mitra dalam berbisnis dan semakin sukses serta dapat bersaing dan unggul dibidang usaha yang sejenis.

\section{DAFTAR PUSTAKA}

Ferrinadewi, E. (2008). Merek \& Psikologi Konsumen: Implikasi pada Strategi Pemasaran. Yogyakarta: Graha Ilmu.

Muktar, M., Sukrianti, S., \& Nurif, M. (2015). Pengaruh Packaging Dalam Meningkatkan Hasil Produksi Terhadap Konsumen. Jurnal Sosial Humaniora, 8(2).

Philip, K. (2008). Manajemen Pemasaran,Analisis Perencanaan Implementasi Dan Pengendalian,. Jakarta: Prenhallindo.

Tjiptono, F. (2005). Pemasaran Jasa (Pertama). Yogyakarta: Penerbit Bayumedia Publishing.

Wijayanti, T. (2012). Marketing plan! Dalam bisnis second edition. Jakarta: PT Elex Media Komputindo.

\section{(c) (i)}

(C) 2019 Oleh authors. Lisensi Jurnal Solma, LPPM-Uhamka, Jakarta. Artikel ini bersifat open access yang didistribusikan di bawah syarat dan ketentuan Creative Commons Attribution (CC BY) license. (http://creativecommons.org/licenses/by/4.0/). 